\title{
Penggunaan Media Sosial dan Literasi Hukum Di Kalangan Ibu PKK
}

\author{
Sri Astutik ${ }^{\text {a,1, }}$ Zulaikha ${ }^{\text {b,2, }}$, Bachrul Amiq ${ }^{\text {c,3 }}$ \\ a,c Fakultas Hukum, Universitas Dr. Soetomo* \\ ${ }^{\mathrm{b}}$ Fakultas Ilmu Komunikasi, Universitas Dr. Soetomo \\ ${ }^{1}$ sri.astutik@unitomo.ac.id \\ *korespondensi penulis
}

Naskah diterima: 29 Januari 2020, direvisi: 10 Februari 2020, disetujui: 17 Maret 2020

\begin{abstract}
Abstrak
Media sosial tidak asing lagi digunakan oleh seluruh lapisan masyarakat, termasuk ibuibu Pembinaan Kesejahteraan Keluarga (PKK). Para ibu memanfaatkan fitur grup baik itu dalam format Facebook atau WhatsApp, yang banyak digunakan untuk berkomunikasi khusus dalam konteks tertentu. Jika itu Grup PKK, maka obrolan dalam grup pun juga seputar masalah dan kegiatan PKK. Jika itu grup lain, maka obrolannya pun akan disesuaikan dengan tema dan anggota grup tersebut. Dengan grup, informasi bisa sampai kepada seluruh anggota dengan cepat dan dalam waktu yang bersamaan. Tetapi belum semua orang memanfaatkan obrolan (chatting) itu dengan bijak dan cerdas. Akibatnya, banyak terjadi perselisihan akibat salah paham dalam obrolan di grup. Selain etika berkomunikasi, menggunakan media sosial juga harus dibarengi dengan literasi tentang hukum dan tata bahasa. Pada pengabdian masyarakat ini, dilakukan sosialisasi tentang bagaimana cara cerdas menggunakan media sosial, agar tidak terjerat hukum. Sosialisasi dilakukan dengan metode ceramah dan diskusi. Materi tentang hukum dan media massa ini diambil, setelah dilakukan pengamatan selama setahun. Hasilnya masih banyaknya ibu-ibu PKK yang belum paham sepenuhnya bahwa pesan dan kirimannya di media sosial bisa terkena jeratan hukum. Setelah dilakukan sosialisasi, peserta semakin tertarik untuk memanfaatkan media sosial dengan positif dan mengambil keuntungan dari media sosial tersebut.
\end{abstract}

Kata-kata kunci: Ibu-ibu PKK; Media Sosial; Literasi; Hukum

Abstract
Social Media is no longer familiar to use by all walks of life, including mothers of
Family Welfare Development (PKK). Mothers utilize the group's features either in
Facebook or WhatsApp format, which are widely used to communicate specifically in
certain contexts. If it's a PKK group, then in-group chats are also about PKK issues
and activities. If it's another group, then the chat will be adjusted to the theme and
members of the group. With groups, information can reach all members quickly and at
the same time. But not everyone makes use of the chat (chat) wisely and intelligently.
As a result, many disputes occur due to misunderstood in the group chat. In addition to
ethical communication, using social media must also be accompanied by literacy
about law and grammar. At this community service, socialization about how smart is
using social media, so as not to be caught by law. Socialization is done by lecture and
discussion methods. The material about the law and the mass media was taken, after a
year of observation. The result is still many mothers of PKK who do not fully
understand that the message and its posts on social media can be exposed to the law.
After socialization, participants were increasingly interested in utilizing social media
positively and taking advantage of the social media.

Keywords: PKK mothers, social Media, literacy, law 


\section{PENDAHULUAN}

Kehidupan manusia tidak bisa dipisahkan dengan penggunaan internet diberbagai bidang kehidupan termasuk penggunaan media sosial. Berdasarkan data UNESCO yang dikutip dari Kominfo (2019) menyimpulkan bahwa 4 dari 10 orang di Indonesia sangat aktif menggunakan media sosial, seperti: Facebook yang memiliki 3,3 juta pengguna, kemudian WhatsApp dengan jumlah 2,9 juta pengguna, dan media sosial lainnya. Selaras dengan data Asosiasi Penyelenggara Jasa Internet Indonesia (APJII) dikutip dari Kompas (2018) pengguna internet di Indonesia lebih dari $50 \%$ dari jumlah penduduk di Indonesia atau sekitar 143 juta orang Indonesia. Berdasarkan data tersebut, angka penggunaan media sosial oleh masyarakat Indonesia sangat tinggi.

Media sosial sangat bermanfaat bagi kehidupan manusia, bahkan masyarakat sangat ketergantungan dalam menggunakan media sosial seperti untuk berinteraksi dengan orang lain lewat dunia maya, media komunikasi, penyebaran berbagai informasi, menjadi sarana untuk berbisnis, memasan alat transportasi, dan sebagainya. Namun disisi lain terdapat dampak negatif bagi penggunanya meliputi: membuat risiko penyebaran konten negatif, penyebaran pesan provokasi, dan ujaran kebencian dapat menimbulkan konflik. Bahkan di era kampanye pemilihan umum 2019, terutama
Pilpres, berita-berita yang belum tentu kebenarannya dan ujaran kebencian sangat mudah didapatkan di media sosial Indonesia.

Di era teknologi informasi sekarang ini, kebutuhan berinteraksi dengan menggunakan media sosial merupakan kebutuhan primer yang harus terpenuhi. Sayangnya, tidak semua orang bisa menggunakan dan memanfaatkan media sosial dengan bijaksana. Hal itu tidak lepas dari terbatasnya literasi yang dimiliki masyarakat utamanya di kalangan ibu-ibu.

Meskipun Undang-Undang Informasi dan Transaksi Elektronik (UU ITE) sudah diundangkan sejak tahun 2008 dan sudah dilaksanakan sejak 2010, tetapi masih banyak masyarakat yang belum sepenuhnya memahami, bahwa berkomunikasi dengan menggunakan media sosial juga bisa terjerat hukum. Kasus terakhir adalah 3 ibu yang mengadakan kampanye hitam Jokowi (menyebarkan hoax tentang Jokowi), mereka terjerat UU ITE. Sebelumnya juga pernah terjadi kasus guru sekolah yang terkena jerat UU ITE karena menyebarluaskan pelecehan seksual yang dilakukan Kepala Sekolah kepadanya. Alih-alih jadi korban, justru si ibu guru ini menjadi tersangka kasus pelanggaran UU ITE, juga kasus Ratna Sarumpaet dan Ahmad Dani, yang diproses di pengadilan. 
Kurangnya literasi hukum membuat masyarakat tidak sadar bahwa dirinya telah melakukan pelanggaran terhadap aturan hukum. Tidak saja mereka dapat dijatuhi hukum pidana penjara, tetapi juga pemberian ganti rugi menurut hukum perdata. Kasuskasus bullying lewat media sosial dapat menyebabkan dampak psikis kepada korban. Namun banyak ibu-ibu yang tidak memberikan penjelasan kepada anak-anak mereka dengan benar, karena keterbatasan pengetahuan dalam hal komunikasi lewat media sosial. Dengan demikian anak-anakpun menjadi tidak tahu dan kurang bijak dalam ber media sosial, meskipun banyak anak-anak muda perkotaan yang sudah dapat memanfaatkan media sosial untuk hal-hal yang positif.

Dengan berbagai latar belakang pendidikan dan pekerjaan yang beragam, masyarakat RW 04 Deles, Kelurahan Klampis Ngasem, Sukolilo, kota Surabaya tentu saja mempunyai karakteriristik yang berbeda beda pula. Fenomena kebutuhan akan media sosial yang menjadi trend saat ini, juga mempengaruhi gaya hidup warga Deles RW 04. Penggunaan media sosial sudah menjadi kebutuhan pokok, karena orang akan merasa bingung dan merasa kurang jika tidak membawa atau ketinggalan gadget nya. Sejak 2002 media sosial menjadi suatu kebutuhan bagi masyarakat untuk berinteraksi dengan orang lain.5 Namun tidak jarang, masih banyak masyarakat yang belum paham bagaimana cara menggunakan media sosial secara bijaksana, agar tidak melanggar aturan yang berakibat sanksi pidana penjara dan ganti rugi. Hal ini dikarenakan yang bersangkutan dinilai menyebarkan kebencian, mengancam, dan menyebarkan informasi bohong (hoax).

Tidak jarang dalam berinterkasi dengan menggunakan media sosial akan menimbulkan konflik. Grup-grup WhatsApp yang memang dibentuk untuk melancarkan komunikasi antar anggota menjadi 'medan peperangan' baru para anggotanya, akibat kurangnya kefasihan dalam berolah bahasa media sosial. Sebagaimana diketahui, bahasa tulis dan bahasa lisan tentu berbeda, dampaknya pun juga berbeda untuk para comunicate (peserta komunikasi). Oleh karena itu ada hal yang perlu diperhatikan dalam hal aktivitas online yang dilakukan ini. Jangan sampai apa yang dilakukan dalam komunikasi online, menjadi hal yang berbenturan dengan etika komunikasi dan hukum sehubungan dengan adanya UU ITE.

Sebetulnya, sisi positif bermedsos pun juga sudah dirasakan oleh warga. Misalnya media sosial juga mempunyai peran yang sangat penting dalam mendukung setiap kegiatan yang dilakukan warga RW 04 Deles Kelurahan Klampis Ngasem. Berbagai 
kegiatan warga dan prestasi warga diinformasikan lewat media sosial, utamanya grup WhatsApp. Era narsis dan selfi mendukung kegiatan warga, sehingga warga bisa lebih akrab dan lebih berbangga dengan fitur-fitur di gadget yang semakin canggih memungkinkan orang berkumpul dan berkegiatan atau melakukan suatu gerakan dengan cepat. Media sosial terbukti sangat membantu warga dalam melakukan komunikasi dan berbagai kegiatan menjadi lebih mudah.

Penggunaan media sosial ini selain mempunyai dampak positif juga mempunyai dampak negatif, jika tidak tepat dalam menggunakannya, bahkan dapat mempunyai akibat hukum yang dapat menjerat penggunanya masuk dalam kategori tindak pidana yang dapat dijatuhi hukuman penjara. Selain hukuman penjara, pelaku dapat juga diminta bertanggungjawab dengan memberikan ganti rugi jika menimbulkan kerugian bagi orang lain, baik materiil maupun imateriil.

Media sosial tidak asing lagi digunakan oleh seluruh lapisan masyarakat, termasuk ibu-ibu Pembinaan Kesejahteraan Keluarga (PKK). Para ibu memanfaatkan fitur grup baik itu dalam format Facebook atau WhatsApp, yang banyak digunakan untuk berkomunikasi khusus dalam konteks tertentu.
Jika itu Grup PKK, maka obrolan dalam grup pun juga seputar masalah dan kegiatan PKK. Jika itu grup lain, maka obrolannya pun akan disesuaikan dengan tema dan anggota grup tersebut. Dengan grup, informasi bisa sampai kepada seluruh anggota dengan cepat dan dalam waktu yang bersamaan. Tetapi belum semua orang memanfaatkan obrolan (chatting) itu dengan bijak dan cerdas. Akibatnya, banyak terjadi perselisihan akibat salah paham dalam obrolan di grup. Selain etika berkomunikasi, menggunakan media sosial juga harus dibarengi dengan literasi tentang hukum dan tata bahasa.

Pada pengabdian masyarakat ini, dilakukan sosialisasi tentang bagaimana cara cerdas menggunakan media sosial, agar tidak terjerat hukum. Sosialisasi dilakukan dengan metode ceramah dan diskusi. Materi tentang hukum dan media massa ini diambil, setelah dilakukan pengamatan selama setahun. Hasilnya masih banyaknya ibu-ibu PKK yang belum paham sepenuhnya bahwa pesan dan kirimannya di media sosial bisa terkena jeratan hukum. Setelah dilakukan sosialisasi, peserta semakin tertarik untuk memanfaatkan media sosial dengan positif dan mengambil keuntungan dari media sosial tersebut. 


\section{METODE}

Metode pengabdian kepada masyarakat dilakukan dengan melakukan penyuluhan kepada masyarakat di wilayah RW 04 Deles Kelurahan Klampis Ngasem Kecamatan Sukulilo Kota Surabaya.

Pelaksanaan pengabdian masyarakat ini terdiri dari 4 tahapan, yaitu:

1. Pengamatan permasalahan mitra. Pengamatan dilakukan selama setahun, dengan partisipasi aktif dalam lingkungan mitra. Setelah mengetahui dan mendalami permasalahan mitra,

2. Persiapan. Persiapan ini berupa pendekatan kepada pengurus PKK, penyebaran undangan, dan persiapan teknis pelaksanaan.

3. Pelaksanaan sosialisasi,

4. Evaluasi dan pembuatan laporan, serta pembuatan rencana untuk pengabdian masyarakat lanjutan.

\section{HASIL DAN PEMBAHASAN}

Pemahaman tentang hukum yang berkaitan dengan penggunaan media sosial di kalangan ibu-ibu PKK Kelurahan Deles Kecamatan Klampis Ngasem Surabaya ternyata masih pada tahapan permukaan saja. Mereka tahu bahwa bermain media sosial bisa terjerat hukum, tetapi tidak begitu memahami apa saja materi yang punya dampak hukum serta materi hukum apa saja yang bisa mengenainya. Sejauh ini, pemahaman hanya berasal dari informasiinformasi yang didapatkan dari media massa mainstream. Memang kasus-kasus yang menjerat pengguna media sosial bersinggungan dengan hukum banyak diberitakan di media mainstream (terutama televisi) baik di acara berita maupun acaraacara infotainment.

Dalam berinteraksi dengan menggunakan media sosial, dapat menimbulkan konflik yang berbenturan dengan peraturan hukum yang berlaku, sebagaimana diatur dalam Pasal 27 ayat (3) UU ITE Nomor 11 Tahun 2008, menyebutkan bahwa "setiap orang dengan sengaja dan tanpa hak mendistribusikan atau mentrasmisikan atau membuat dapat diaksesnya informasi elektronik atau dokumen elektronik yang bermuatan penghinaan atau pencemara nama baik" (Kementerian Komunikasi dan Informatika. 2008). Berdasarkan UU tersebut, dalam menggunakan media social perlu diperhatikan jangan sampai konten di media social dapat melanggar UU ITE dengan melakukan penghinaan maupun mencemarkan nama baik seseorang.

Adapun penjelaskan tentang pencemaran nama baik dipaparkan dalam Pasal 310 ayat (1) KUHP, "penghinaan yang dapat dipidanakan jika dilakukan dengan cara 
menuduh seseorang telah melakukan perbuatan yang tertentu yang dapat diketahui orang banyak (gresnews. 2014). Pencemaran nama baik dapat dilakukan baik secara lisan maupun tulisan. Media social dapat menjadi sarana untuk melakukan pencemaran nama baik kepada seseorang melalui tulisan di media social. Menurut UU ITE, ada tiga unsur yang harus dicermati yaitu :

1. unsur kesengajaan melakukan pencemaran nama baik di media social,

2. konten di media social syarat muatan pencemaran nama baik,

3. pencemaran nama baik disebarkan luaskan ke jejaring social.

Jika terjadi pelanggaran pencemaran nama baik di media social, maka akan terancam pidana penjara atau denda, sebagaimana yang ditegaskan dalam UU ITE dalam 45 yang berbunyi: "setiap orang yang dengan sengaja mendistribusikan serta membuat konten bermuatan pencemaran nama baik akan dikenakan sanksi penjara paling lama 4 tahun atau denda paling banyak Rp 750.000.000”. Dari aturan tersebut, pelanggar dapat dikenakan sanksi yang tegas jika terbukti melakukan pencemaran nama baik. Oleh karena itu, perlu adanya etika yang mengatur komunikasi di media social agar tidak melanggar hukum.

Memperhatikan etika komunikasi di media sosial sangat penting untuk dilakukan, oleh karena itu akan dipaparkan sebagai berikut:

1. Penggunaan kalimat dalam berkomunikasi di media social dapat diperhatikan dengan menggunakan kalimat yang baik dan menghindari kalimat yang mengandung ambigu yang dapat memicu kesalahpahaman.

2. Perhatikan warna tulisan agar tidak menimbulkan kesalahpahaman.

3. Perhatikan penggunaan huruf yang sesuai besar kecilnya huruf dapat mempengauhi komunikasi di media social.

4. Komunikasi di media social dapat menggunakan bahasa yang sopan.

5. Perhatikan pemilihan simbol atau ikon yang tepat dalam berkomunikasi di media social.

6. Segera memberikan respon dalam berkomunikasi.

7. Informasi yang diberikan adalah benar serta memiliki referensi yang dapat dipertanggungjawabkan.

8. Komunikasi di media social dengan baik sehingga tidak memancing pertentangan atau konflik.

Media sosial memiliki fungsi untuk membantu melakukan komunikasi dengan orang lain, sehingga jangan sampai media sosial justru memicu permasalahan akibat etika dalam berkomunikasi yang tidak diperhatikan. 
Meskipun semua orang Indonesia menguasai bahasa Indonesia, tetapi tidak semua orang bisa menggunakannya dengan benar dan tepat. Apalagi, dalam pergaulan, masih juga dikenal ragam bahasa gaul, dialek, kosa kata dari bahasa daerah yang dicampuradukkan dalam bahasa lisan seharihari. Tidak semua orang punya keterampilan menulis lengkap dengan pengetahuan tentang bahasa yang baik dan benar. Komunikasi di media sosial lebih banyak dengan tulisan dan bahasa tulis, maka banyak menimbulkan kesalahpahaman akibat perbedaan persepsi yang timbul dari tulisan itu. Bahasa lisan merupakan bahasa yang diucapkan seseorang dengan menggunakan mimik, intonasi, dan gerakan tubuh. Dengan menggunakan bahasa lisan maka dapat dilakukan untuk berdebat, berkomentar, dan berdiskusi. Walaupun apa yang keluar dari mulut tidak sama persis seperti yang dipikirkan atau diinginkan, tetapi lebih mudah untuk diralat dan dikoreksi, terutama dalam hal berdebat atau adu argumen. Juga dalam hal bersendagurau. Ditambah lagi emosi atau perasaan lawan bicara juga lebih mudah dipahami karena bertatap muka secara langsung.

Bahasa tulisan merupakan bahasa yang dihasilkan dengan berbagai huruf sehingga menjadi sebuah kalimat utuh. Dalam menggunakan Bahasa tulisan perlu diperhatikan terkait dengan tata bahasa yang digunakan seperti perhatikan susunan kalimat, menggunakan kata-kata yang tepat, penggunaan ejaan atau tanda baca perlu diperhatikan. Dalam bahasa tulis dibantu dengan emoticon, tetap saja aura dan nada bicara tidak bisa terwakili. Pemilihan kata atau istilah salah sedikit saja bisa menimbulkan ketersinggungan. Salah ketik juga bisa menjadi bencana, apabila huruf yang salah itu membentuk kata berbeda dengan makna yang sangat melenceng dari tujuan.

Dalam bermedia sosial, terutama di grup-grup yang beranggotakan ibu-ibu dengan tema tertentu (grup arisan, grup pengajian, grup panitia kegiatan) banyak terjadi kesalahpahaman yang berujung perdebatan tiada akhir. Para ibu PKK sering berdebat, bertengkar dan bermusuhan di media sosial yang dapat mempengaruhi interaksi di dunia nyata.

Tim pengabdi memberikan solusi terhadap masalah tersebut yaitu dengan memberikan pengetahuan serta membukakan mindset para ibu PKK untuk menggunakan media social seacara bijak dan baik. Dalam kegiatan pengabdian masyarakat ini tidak hanya dilakukan penyuluhan materi tentang menggunakan media social yang baik, tetapi juga menonton video-video psikologi tentang etika berkomunikasi yang baik di media social. 
Seringkali masyarakat kurang tertuang dalam Undang-Undang memperhatikan etika penulisan di media Perlindungan Data Pribadi, meskipun social, banyak juga yang menganggap bahwa tidak melakukan niat melakukan pelanggaran tetapi hanya berniat bercanda, meskipun pada akhirnya dapat menimbulkan kesalahpahaman bagi pembaca.

Kegiatan pengabdian masyarakat ini berjalan dengan lancar dari awal sampai akhir kegiatan. Para ibu PKK sangat antusias dalam mengikuti kegiatan penyuluhan ini, terbukti dengan berbagai pertanyaan yang diajukan kepada tim pengabdi. Salah satu pertanyaan yang diajukan terkait dengan kartu identitas kependudukan sudah berbasis digital, apakah bisa dimanfaatkan untuk melakukan kejahatan?, dan apakah informasi kependudukan itu aman?

Untuk menjawab hal ini, harus mengacu pada 4 Undang-undang yang relevan dengan permasalahan yakni : (1) UU no. 12/2006 tentang Kewarganegaraan Republik Indonesia, (2) UU No. 23/2006 tentang Administrasi Kependudukan, (3) UU No. 52/2009 tentang Perkembangan Kependudukan dan Pembangunan Keluarga, serta (4) UU No. 24/2013 tentang Perubahan Atas UU No. 23/2006 tentang Administrasi Kependudukan. Berdasarkan UndangUndang tersebut memberikan perlindungan tentang data kependudukan.

Saat ini pemerintah mempersiapkan regulasi perlindungan data pribadi yang akan sebetulnya selama ini juga sudah dilindungi dengan keempat UU tersebut, juga (1) UUD 1945, (2) UU No. 39/1999 tentang Hak Asasi Manusia, (3) UU No. 11/2008 tentang Informasi dan Transaksi Elektronik, serta (4) UU No. 14/2008 tentang Keterbukaan Informasi Publik.

Dalam Draft UU Perlindungan Data Pribadi disebutkan bahwa penyalahgunaan data pribadi untuk kepentingan tindak pidana, diancam pidana selama 1 tahun penjara dan atau denda Rp 300.000.000, apabila dilakukan oleh perorangan, dan denda Rp 1.000.000.000 apabila kejahatan itu dilakukan oleh badan hukum. Dalam mengawal UU Perlindungan Data Pribadi ini, pemerintah dibantu oleh Komisi Informasi Pusat. Komisi Informasi selama ini diketahui mengawal UU No. 14 tahun 2008 tentang Keterbukaan Informasi Publik, tetapi karena lingkup kerjanya tentang informasi, maka informasi privat pun masuk dalam ranah Komisi Informasi. Meski demikian, sengketa atas informasi privat tidak secara tegas disebutkan dalam Draft UU Perlindungan Data Pribadi, bisa dilakukan di Komisi Informasi, yang selama ini tugasnya memang menyelesaikan sengketa tentang informasi publik. Penyelesaian sengketa dalam draft UU Perlindungan Data Pribadi, hanya disebutkan 
bisa diselesaikan melalui pengadilan atau di luar pengadilan.

Permasalahan lain yang menjadi pertanyaan warga adalah apakah media sosial mempegaruhi perkembangan jiwa anak. Untuk mejelaskan hal ini, maka literasi dan budaya membaca harus ditingkatkan, terlebih di kalangan ibu-ibu. Seorang ibu harus cerdas sehingga dapat memberikan penjelasan yang ilmiah dan masuk akal kepada anak-anaknya mengenai segala informasi dan tayangan yang diperolehnya dari media sosial. Dengan demikian, si anak tertular juga untuk cerdas menghadapi serbuan informasi dari media sosial.

Upaya yang dapat dilakukan dalam melindungi anak dari berbagai dampak negatif dari komunikasi di media social. Perlu adanya pengetahuan tentang penggunaan media social yang baik, memupuk nilai-nilai norma dan karakter sehingga dapat memfilter hal negative di media sosial.

Seiring dengan perkembangan teknologi informasi, maka proses sosialisasi kini tak lagi hanya dilakukan melaui interaksi secara langsung, tetapi juga dengan menggunakan alat komunikasi digital yang memiliki akses tanpa batas. Sama halnya dengan interaksi langsung, anak bisa saja bertumbuh dalam pergaulan yang kurang bermanfaat, demikian juga interaksi digital. Jadi pantauan cerdas dari orang tua tetap diperlukan untuk dapat memantau anak menggunakan internet yang sehat. Sebagaimana yang diungkapkan oleh Suharyadi (2019) penyuluhan tentang internet sehat dapat memberikan pemahaman kepada masyarakat sebagai solusi bijak untuk mencegah dampak negatif dari penggunaan media sosial.

Kegiatan pengabdian masyarakat yang dilakukan kepada ibu-ibu PKK tentang penggunaan media sosial pernah dilakukan oleh Luhukay (2018) hasil pengabdian didapatkan bahwa penyuluhan kepada ibuibu PKK tentang media social sangat penting dilakukan untuk dapat memfilter informasi yang tepat sebagai solusi untuk mencegah keberadaan hoax. Selaras dengan pengabdian kepada masyarakat yang dilakukan Nursyifa (2019) adanya peningkatan pemahaman para ibu tentang dampak negatif teknologi bagi anak-anak, sebagai upaya melakukan kontrol social agar tidak terjerumus pada perilaku menyimpang. Wardhaningsih pelatihan literasi media sosial penting dilakukan kepada para ibu untuk bijak menggunakan media sosial, sehingga dapat memberikan pengajaran kepada anak-anak untuk menggunakan media sosial dengan baik.

Berdasarkan hasil pengabdian masyarakat tersebut, maka penyuluhan tentang penggunaan media sosial sangat penting dilakukan, sebagai upaya memberikan literasi tentang penggunaan 
media sosial yang baik untuk masyarakat dan tidak melanggar hukum.

\section{KESIMPULAN}

Dalam kegiatan pengabdian masyarakat pada warga di wilayah RW 04 Deles Kelurahan Klampis Ngasem Kecamatan Sukulilo Kota Surabaya, selain memberikan solusi terhadap masalah mitra tentang jerat hukum dalam penggunaan media sosial yang tidak sesuai dengan etika komunikasi dan ketentuan undang undang, juga memunculkan masalah-masalah baru yang ingin diketahui dan dipahami oleh warga terkait dengan penggunaan media sosial.

Dari hasil pengabdian ini dapat ditindaklanjuti untuk melaksanakan kegiatan pengabdian berikutnya. Ibu-ibu PKK sangat antusias menggunakan dan memanfaatkan media sosial untuk bisnis, karena telah terbukti perkembangan teknologi informasi bisa meningkatkan kesejahteraan keluarga. Ibarat pisau bermata dua, teknologi informasi bisa sangat membantu kehidupan, jika manusianya bisa cerdas dan bijak dalam meman-faatkannya. Tetapi bisa juga berefek negatif apabila tidak selektif dan hanya mengikuti hawa nafsu duniawi semata.

Disarankan bagi masyarakat harus lebih bijak dan hati-hati dalam menggunakan media sosial, baik dalam berkomunikasi antara sesama warga, juga saat bertransaksi dan berbisnis dengan menggunakan media sosial atau on line.

\section{REFERENSI}

Gresnews. (2014). Pencemaran Nama Baik. Diakses pada https:// www. gresnews. com/ mobile/berita/ tips/ 81504. Diakses pada 21 April 2019.

Kementerian Komunikasi dan Informatika. (2008). Undang-Undang Nomor 11 Tahun 2008 tentang Informasi dan Transaksi Elektronik. Diakses https://jdih.kominfo.go.id/produk_huk um/view/id/167/t/undangundangnomor 11tahun2008tanggal21april2008.

Diakses pada 21 April 2019.

Kominfo. (2019). Angka Penggunaan Media Sosial Orang Indonesia Tinggi Potensi Konflik. Diakses http://kominfo. go.id/ content/ detail /14136. Diakses pada 21 April 2019.

Kompas. (2018). Jumlah Pengguna Internet di Indonesia. Diakses https://tekno.kompas.com/read/2018/0 2/22/16453177/berapa-jumlahpengguna-internet-indonesia. Diakses pada 21 April 2019.

Luhukay, M. S. (2018). Penyuluhan Literasi Media: Cara Mencegah Hoax Di Media Sosial Kepada Ibu-Ibu PKK Kelurahan Pakulonan Barat Tangerang. Prosiding Konferensi Nasional Pengabdian Kepada 
Masyarakat dan Corporate Social Responsibility (PKM-CSR), 1, 185191.

Nursyifa, A. (2019). The Socialization of the Important of Family Roles as Prevention Actions toward the Negative Impact of Technology on Children in the Digital Age [Sosialisasi Peran Penting Keluarga Sebagai Upaya Pencegahan Dampak Negatif Teknologi pada Anak dalam Era Digital]. Proceeding of Community Development. 2, 648-657. Diakses https://www.researchgate.net/publicati on/331551320

Suharyadi, S., \& Maria, E. (2019). Internet Sehat: Solusi Bijak Masyarakat Desa Doplang, Kabupaten Boyolali. Intervensi Komunitas, 1(1), 72-80.

Wardhaningsih, A. D., \& Pamungkas, S. (2019). Pelatihan Literasi Media Menghadapi Era Industri 4.0 Bagi Ibu Rumah Tangga Di Daerah Tangerang. Prosiding Konferensi Nasional Pengabdian Kepada Masyarakat dan Corporate Social Responsibility (PKMCSR), 2, 932-944. 
Biarkan halaman ini tetap ada

[ halaman ini sengaja dikosongkan ] 